\title{
OBSERVATIONS ON THE HAEMORRHAGIC DIATHESIS IN MULTIPLE MYELOMA
}

\author{
Rosalinde Hurley, M.D.(Lond.)* \\ Sidney Shaw, M.D.(Lond.) \\ Department of Hamatology, Charing Cross Hospital and Medical School, London
}

\begin{abstract}
AbNormal bleeding has been recognized as a presenting symptom in multiple myeloma (Wintrobe, 196I) though less frequently encountered than pain, tumours, deformity, pathological fractures and neuralgic or neurological symptoms. Bernard, Inceman, Zara and Christol (1952) comment that hæmorrhage is found more frequently as a secondary or terminal feature than as a presenting symptom, but concede that it is common. In their series of 100 cases hæmorrhage was present in 37 , in 18 cases moderate and in I9 cases severe. Of 13 cases described by Rosenthal and Vogel (1937) hæmorrhage occurred in five. While Lichtenstein and Jaffé (1947) do not include abnormal bleeding as a common presenting symptom, they refer to a purpuric tendency and call attention to a disorder of the clotting mechanism, characterized by poor clot retraction, which may occur. Osserman comments on bleeding into the gastro-intestinal tract as a feature of the disease (I959).

It is the purpose of this paper to report a case of multiple myeloma in which the presenting symptoms were those of hæmorrhage, together with an investigation into the nature of the abnormal bleeding.
\end{abstract}

\section{Case Report}

A female, aged 40, was first seen in Moorfields Eye Hospital five days after she had noticed a ' reddish blur' over the left eye. On examination of the fundus the retinal veins were seen to be turgid and there were retinal hæmorrhages. Increase in the viscosity of the blood was noted and it was thought this might be causing retinal vein obstruction. Hess's test was positive. She was referred for a further opinion and admitted to a general hospital two days later.

She complained of tiredness and flagging energy for several months and of severe headache. She was unable to read due to blurring of vision in the left eye. Her last three periods had been excessively heavy, the menses soaking rapidly through sanitary towels and on occasion soiling her outer garments. During her last period, a fortnight before admission, she had passed several large clots. After her periods she felt exhausted. In the past six months she had had frequent epistaxes. For a few weeks she had noticed shortness of breath. For as long as she could remember she had always bled for several hours following tooth extraction. Since

\footnotetext{
*Present address: Queen Charlotte's Maternity
} Hospital, London, W.6. the birth of her child i I years before (F.T.N.D.) she had suffered from bleeding piles. There was no historyes of hæmoptysis, hæmatemesis, melæna, hæmaturia or $\vec{\circ}$ purpura. There was no family history of anæmia or:abnormal bleeding.

On examination she was a pale, ill-looking woman with a muddy complexion. There was marked pallor of themucous membranes, but no jaundice. There was no을 purpura and Hess's test was negative. The temperature and pulse rate were normal. The liver and the spleen were each enlarged two fingers' breadth. There were no other physical signs except a grade two systolic murmurcf best heard at the apex and conducted up into the neck.

Investigations. ESR (Westergren) $140 \mathrm{~mm} . / \mathrm{hr} ., \stackrel{\infty}{\infty}$ $\mathrm{Hb} 33 \%(4.8$ g. $\%$ ), r.b.c. 1,240,000/cu. mm., CI 1.30,

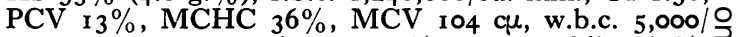
cu. mm., metamyelocytes $3 \%$, neutrophils $64 \%,-$ eosinophils $3 \%$, monocytes $3 \%$, lymphocytes $24 \%$, D plasma cells $3 \%$, reticulocytes $8 \%$, platelets $187,000 /$ C cu. $\mathrm{mm}$. The stained film showed moderate anisocytosis and polychromasia and slight hypochromia. Occasional macrocytes were present and there were two late normo- $\overrightarrow{0}$ blasts per 100 nucleated cells. One binucleated plaspha cell was seen. There was also marked rouleaux formation. Prothrombin time: 27 seconds with a control of $\bar{\Phi} \square$ seconds. Bleeding time (Duke's): 30 minutes. Clotting time (Lee and White's): 8 minutes. Blood group $\mathrm{O}$ rhesus-negative to anti-D. Red cell fragility normal. Coombs test: negative. Examination for L.E. cells negative. Serum $\mathrm{B}_{12}$ : ${ }_{132} \mu \mu \mathrm{g} . / \mathrm{ml}$. (L. leichmanii method). Serum bilirubin: $0.7 \mathrm{mg} . / 100 \mathrm{ml}$. Urinary urobilinogen was not increased. Blood urea: $30 \mathrm{mg} . / \overrightarrow{\vec{\sigma}}$ $100 \mathrm{ml}$. Albumin was present in the urine, but no Bence $\frac{\text { 의 }}{3}$ Jones protein was detected. No cells or casts were seen in the centrifuged deposit. Total serum protein: 14.0 g. $/ 100 \mathrm{ml}$. Albumin 2.1, globulin $11.9, \mathrm{~A} / \mathrm{G}$ ratio $0.2: 1$. The electrophoretic pattern showed a gross excess of gamma globulin. Serum calcium: $9.2 \mathrm{mg}$. $100 \mathrm{ml}$.

In view of the disorder of the clotting mechanism, blood was cross-matched before the sternal marrow was aspirated. This marrow showed the presence of $O$ numerous plasma cells (approximately $25 \%$ of the total nucleated cells) and also partially megaloblastic erythro-응 poiesis. The appearances were compatible with myelomatosis.

A chest X-ray showed some cardiac enlargement with enlargement of the pulmonary conus and of the main $N$ pulmonary vessels. The appearances were compatible ${ }^{\circ}$ with a hyperdynamic circulation. No lung lesion was $N$ seen. X-ray of the lumbar spine and pelvis showed the bones to be slightly osteoporotic. There was also some $\omega$ suggestion of multiple translucencies in the ischialo bones. These appearances were thought to be the early changes of multiple myeloma. The skull X-ray was within normal limits.

Clinical Course and Treatment. The diagnosis made $\stackrel{\text { ? }}{+}$ on these findings was multiple myeloma. The patient $T$ was transfused with 4 pt. of whole blood and the hæmo-음 globin rose to $51 \%(7.5 \mathrm{~g} . \%)$. 
She was started on a course of prednisolone, on which she remained until her death three to four weeks later. A further transfusion of 4 pt. of packed cells was given. Meanwhile the pains in her back and legs gradually grew worse and she required morphine. Before death she was bleeding heavily per vaginam and had a hæmatoma over the left buttock and a left hemiparesis.

Subsequent Investigations. The great viscosity of the blood and poor clot retraction made investigations difficult. Serum was separated off with difficulty even at $37^{\circ} \mathrm{C}$. Blood for the last transfusion could be crossmatched only by the Coombs technique owing to marked rouleaux formation.

The total serum protein before death was $16.7 \mathrm{~g}$./100 $\mathrm{ml}$., of which only $1.9 \mathrm{~g}$. was albumin and the rest globulin. The formol gel test was positive and the Kunkel test greater than ro units. The daily urine output was I to 21 . On admission the average daily output of protein in the urine was 2 to $3 \mathrm{~g}$./1. (Esbach), but this output steadily rose and terminally was variable with a maximum of $10 \mathrm{~g}$. $/ \mathrm{l}$. and an average of $7 \mathrm{~g} . / 24 \mathrm{hr}$.

Viscosity studies using a capillary frame viscometer showed a plasma viscosity about seven times greater than normal and a whole blood viscosity about two and a half times the normal in the later stages of her illness. The hæmoglobin before death was $54 \%(8.0 \mathrm{~g} . \%) .{ }^{59} \mathrm{Fe}-$ uptake test showed that the bone marrow wes almost entirely non-functioning. The erythrocyte sedimentation rate remained elevated and was last recorded as a fall of $168 \mathrm{~mm}$./hr. (Westergren). Terminally there was a leucocytosis of 40,000 cells/ cu. $\mathrm{mm}$. with $50 \%$ plasma cells and the blood urea was $64 \mathrm{mg} . \%$.

Investigation of Bleeding Diathesis. Initially the patient was found to have a prolonged prothrombin time (27 seconds with control of 17 seconds), a normal clotting time and a prolonged bleeding time (30 minutes). The platelet count at that time was $123,000 / \mathrm{cu}$. $\mathrm{mm}$. Clot retraction was noted to be consistently poor.

An injection of vitamin $\mathrm{K}$ was given and the patient transfused with $4 \mathrm{pt}$. of whole blood. Thereafter the bleeding time was ro minutes and the prothrombin time 3 I seconds with control of 17 seconds. The platelet count was $98,000 / \mathrm{cu}$. $\mathrm{mm}$.

The prothrombin time repeated a week later was 25 seconds with a control of 17 seconds. The thromboplastin-generation test showed no evidence of deficiency of antihæmophilic globulin, Christmas factor or the Stuart-Prower factor. Platelet thromboplastic function was normal and there was no evidence of a circulating anticoagulant. By mutual correction studies using the thromboplastin-generation test with known Factor V, Factor VII and prothrombin-deficient blood samples, and by the two-stage prothrombin test, the prolongation in the prothrombin time was shown to be due to a Factor VII deficiency, with no deficiency of Factor V or prothrombin. The serum fibrinogen was $250 \mathrm{mg}$./ $100 \mathrm{ml}$. (biuret).

Necropsy Findings. Death was due to pulmonary œdema. There were scanty cutaneous petechial hæmorrhages. The principal pathological findings were: pulmonary œdema and left ventricular hypertrophy, anæmia, petechial hæmorrhages in the brain and the heart, and multiple myeloma affecting bone, spleen and probably liver. The marrow of the sternum, ribs, vertebræ and right femur was diffusely infiltrated by soft greyish semi-translucent tumour tissue which in places was hæmorrhagic. The spleen was grossly enlarged $(1,078 \mathrm{~g}$.) and markedly congested with irregular areas (up to $\mathrm{I} \mathrm{cm}$. diameter) of greyish tissue throughout its substance. The liver was markedly enlarged $(2,704$ g.), pale and fatty. Histologically, there was multiple myeloma invading bone, liver, spleen and lymph nodes.
The kidney was abnormal with deposits of protein. There was no evidence of amyloidosis.

\section{Discussion}

The ætiology of the abnormal bleeding in multiple myeloma has not been clearly elucidated although it has occasioned much discussion (André, Dreyfus, Jacob and Ley, 1952). It has been explained as secondary to the low platelet count and prolonged bleeding time (Wintrobe, 1961), but the latter may be normal or increased without relation to the platelet count. Moreover, the platelets may be within normal limits. Defective platelet function (thrombocytopathia) has been noted and may contribute to bleeding when the platelet count is normal. In one case giant platelets measuring $5 \mu$ diameter were observed (Czernobilsky and Alexander, I96I). Capillary damage from impaired blood flow due to the often greatly increased blood viscosity has also been considered as a factor in the development of the hæmorrhagic diathesis (de Gruchy, 1958). Since bleeding may occur in other disorders characterized by abnormality of the plasma proteins (Owen and Got, 1960), these may play a more direct ætiological role: possible modes of action of abnormal protein include infiltration of the vascular wall and interference with the mechanism of coagulation (de Gruchy. I958)

A disorder of the clotting mechanism proper has been observed although the essential nature of the disturbance is obscure. Wintrobe ( $196 \mathrm{I}$ ) comments that cutaneous hæmorrhagic manifestations such as purpura and massive subcutaneous hæmorrhages may develop as the result of this disturbance. Failure of clot retraction and subsequent difficulty in obtaining adequate samples of serum for pathological investigations seem to be encountered relatively frequently (Stewart and Weber, 1938). The observation was first recorded by Runeberg in 1883 (Frick, I955). Lichtenstein and Jaffé (1947) commented on failure of clot retraction, and of the five hæmorrhagic cases reported by Rosenthal and Vogel (1937) one showed failure of clot retraction in addition to thrombocytopenia. Four of their 13 cases had platelet counts below 100,000/cu.mm., but the one mentioned above was the only thrombocytopenic case in which there was abnormal bleeding. Osserman (1959) states that in a small number of cases there is a defect in the clotting mechanism, the nature of which he does not specify. He considers that thrombocytopenia, present in about a third of cases, may contribute to bleeding.

The prothrombin time, thrombin time and conversion of fibrinogen to fibrin may all be abnormal. In some cases an anticoagulant (anti- 
thrombin $\mathrm{V}$ ) has been demonstrated. Increase in the one-stage prothombin time (Quick) may be due to the antithrombin, but Verstraete and Vermylen (1959) thought that there was no relationship between the presence of the antithrombin and the hæmorrhagic phenomena which occur in some cases of myelomatosis. Craddock, Adams and Figueroa (1953) confirmed the observations of Lüscher and Labhart (1949) and Uehlinger (1949) that the conversion of fibrinogen to fibrin is prevented by an abnormal plasma protein, and showed that this defect could be largely overcome by the addition of an excess of calcium ions. They offered the conjectural explanation that impairment of fibrinogen conversion may lie partly in deficient availability of ionic calcium due to interference by the abnormal protein, which may be a reflection of its high calcium binding power. Frick (1955), in a study of 45 patients with myeloma, observed abnormal conversion of fibrinogen to fibrin by a circulating anticoagulant in 12 patients. In two, who were studied in detail, the anticoagulant occurred in the beta and gamma globulin fractions. From the available data he concluded that only a severe impairment of fibrinogen conversion, with clot retraction virtually absent, causes hæmorrhagic symptoms per se, but suggested that lesser degrees of this abnormality combined with mild thrombocytopenia induce bleeding. He recalled that uræmia, amyloidosis (Magnus-Levy, 1933) and cryoglobulinæmia (Wintrobe and Buell, 1933) may all contribute to the bleeding.

Bernard and others (1952) considered that the causation of the bleeding is multifactorial, but principally falling into two categories: in the first, bleeding secondary to the low platelet count and ætiologically resembling the hæmorrhages of the leukæmic states; in the second, unrelated to the platelet count. As examples of the second type they cited two cases in which they regarded the cause of the bleeding as the result of a toxic effect of the dysglobulinæmia on the capillaries. They commented that clot retraction is usually normal, prothrombin normal or slightly depressed, the coagulation time usually normal and fibrinogenopenia not found although a qualitative alteration is possible. They placed little emphasis on the disorder of clotting which is sometimes encountered.

It seems likely that any or all of the factors mentioned above may operate to bring about abnormal bleeding in myelomatosis, the interesting feature in the ætiology being the multiplicity of factors which may be contributory.

In our case there was no uræmia, cryoglobulins were not detected and there was no histological evidence of amyloidosis. It seemed unlikely that the bleeding could be attributed solely to thrombocyto- $\frac{0}{0}$ penia since the lowest recorded platelet count was $98,000 /$ cu.mm. Hess's test, however, was found positive on one occasion soon after the observation 읃 of the retinal hæmorrhages. Qualitative deficiency of the platelets was ruled out by demonstration $\overrightarrow{\vec{F}}$ of a normal thromboplastic activity. The bloodo was extremely viscous, particularly in the late음 stages of the illness, so it is possible that capillary $\overline{\overline{\bar{s}}}$. anoxæmia mediated by poor blood flow, or a $\mathbb{Q}$ direct toxic action on vessel walls by abnormal protein, might be an associated cause of hæmor- ${ }^{\circ}$ rhage in this case. There was little evidence to $\vec{\circ}$ support this since there was no external purpura $\overrightarrow{\vec{H}}$ until just before death, and Hess's test, on all $\stackrel{\omega}{\sigma}$ but one occasion, was negative. At necropsy, $\overrightarrow{0}$ however, there were petechial hæmorrhages in the 3 . heart and the brain.

The failure of clot to retract, the prolongation of the bleeding time in the absence of thrombo- $A$ cytopenia and the prolongation of the prothrombin + time led us to suppose that we were dealing with ${ }^{\circ}$ a simple disorder of the clotting mechanism which 을 might explain, either wholly or in part, the hæmorrhagic manifestations. A Factor VII deficiency was demonstrated.

Although the patient had volunteered that from $\stackrel{\frac{D}{+}}{\rightarrow}$ early childhood she had bled for hours followirg $\overrightarrow{0}$ tooth extraction it seemed unlikely that the Factor VII deficiency was congenital in this case There was no family history of anæmia or bleed ing tendencies and there were no other symptoms in early life. Congenital deficiency of Factor VII is a rare disease, the symptoms usually being $\stackrel{\circ}{\Phi}$ severe and manifest in childhood.

The deficiency of Factor VII was probably $\overrightarrow{\overrightarrow{0}}$ related to poor liver function rather than to mal- 3 absorption of vitamin $\mathrm{K}$ since vitamin $\mathrm{K}$ administered parenterally had no effect on the prothrombin time which remained prolonged. During $\frac{0}{3}$ life the liver was palpable and the Kunkel test over ten units indicating derangement of liver 3 . function. At necropsy the liver appeared to be affected by myelomatosis and this was confirmed histologically. It seemed, therefore, that the 0 defect was acquired and probably secondary to liver disease. Another explanation of the Factor VII deficiency might be a qualitative alteration in the clotting factor. Such an effect might be जr produced as a consequence of the abnormal $N$ protein synthesis which characterizes the disease, N the clotting factors themselves being involved in 0 the abnormal and excessive synthesis of protein. Alternatively, deficiency of the factor might have been secondary to the over-elaboration of abnormal $\stackrel{\oplus}{\rightarrow}$ protein replacing normal synthesis of the clotting 0 factors.

Although in this case as in other reported cases 
there was no single factor which could be considered as solely responsible for the hæmorrhagic state, there were a number of additive factors, namely, moderate reduction in Factor VII, greatly increased plasma and whole blood viscosity, abnormal proteins with a marked increase in gamma globulin, and a slightly reduced platelet count. In addition there was a very poor clot retraction, which may have been due to poor conversion of fibrinogen to fibrin (Craddock and others, 1953).

Since it is recognized that increased bleeding with trauma may be induced by a simple failure of the coagulation mechanism alone (Stefanini and Dameshek, 1955), it seemed probable that in our case a moderate deficiency in Factor VII, together with the other factors mentioned above, would suffice cumulatively to explain the clinical state and the abnormal laboratory findings.

Unfortunately the patient died before an attempt could be made to control the bleeding diathesis apart from administration of vitamin $K$. The last blood transfusion she received consisted of packed cells.

The part played by specific defects in the clotting mechanism in multiple myeloma, even where these are of moderate severity, may be of importance clinically, since such defects may be remediable. Even in the presence of thrombocytopenia or other explanation of hæmorrhage it would seem worth while to investigate the clotting mechanism, since this may influence the decision to give transfusions of packed cells or of whole blood, fresh or stored.

\section{Summary}

A case of multiple myeloma is described in which the presenting symptom was retinal hæmorrhage accompanied by epistaxes and recent excessive mentrual bleeding. A disorder of clotting was discovered and a deficiency of Factor VII demonstrated. It is suggested that the clotting mechanism should be investigated in all cases of multiple myeloma in which there is abnormal bleeding, as replacement therapy may be indicated and could, if the defect were severe, ameliorate the course of the disease.

We wish to thank Dr. N. S. Plummer for permission to study and publish this case.

We are especially indebted to Dr. G. D. Pegrum for many useful suggestions and active assistance; to Mrs. Sylvia Wolff (employed by grant from the Charing Cross Hospital Clinical Research Committee) for technical assistance in the coagulation studies; to Dr. Bernard Fox, who carried out the necropsy; to Dr. C. A. F. Joslin for the $\mathrm{Fe}^{59}$ study; and to Dr. M. A. Peyman for the viscosity studies.

\section{REFERENCES}

André, R., Dreyfus, B., Jacob, S., and Ley, G. (1952): Sur les Formes Hemorragiques des Myélomes, Rev. Hemat., 7, 296.

Bernard, J., Inceman, S., Zara, M., and Christol, D. (1952): La Dysglobulinémie Maligne Hémorragipare, Rev. Hémat., 7, 264.

Craddock, C. G., Jr., Adams, W. S., and Figueroa, W. G. (1953): Interference with Fibrin Formation in Multiple Myeloma by an Unusual Protein Found in Blood and Urine, $\mathcal{F}$. Lab. clin. Med., 42, 847.

Czernobilsky, H., and Alexander, B. (I96r): In Henry Ford Hospital International Symposium on Blood Platelets, p. 578 (edited by S. A. Johnson, R. W. Monto, J. W. Rebuck, and Robert C. Hurn, Jr.). London: Churchill.

DE GruCHY, G. C. (1958): 'Clinical Hæmatology in Medical Practice', pp. 388, 389, 497. Oxford: Blackwell.

FrICK, P. G. (1955): Inhibition of Conversion of Fibrinogen to Fibrin by Abnormal Proteins in Multiple Myeloma, Amer. F. clin. Path., 25, 1263.

Lichtenstein, L., and JAFFE, H. L. (1947): Multiple Myeloma; A Survey Based on Thirty-five Cases, Eighteen of which came to Autopsy, Arch. Path., 44, 207.

LüsCHER, E., and LABHART, A. (1949): Blutgerinnungsstörung durch $\bar{\beta} \gamma$-globuline. Zur Kenntniss der Gerinnungsstörungen durch Körpereigene Antikoagulantien, Schweiz. med. Wschr., 79, 598.

Magnus-Levy, A. (1933): Multiple Myelome: Euglobulinämie. Zur Klinik und Pathologie, Z. Klin. Med., 126, 62.

Osserman, E. F. (1959): Plasma-cell Myeloma, 2. Clinical Aspects, New Engl. F. Med., 26r, 952.

OwEN, J. A., and Got, C. (1960): Biological Significance of the Anomalous Serum and Urinary Proteins of Myelomatosis, Lymphoma, and Other Conditions, F. clin. Path., 13, 58.

Rosenthal, N., and Vogel, P. (1937): Value of Sternal Puncture on the Diagnosis of Multiple Myeloma, f. Mt. Sinai Hosp., 4, 1001.

Stefanini, M., and Dameshek, W. (1955): 'The Hemorrhagic Disorders', p. 188. New York and London: Grune \& Stratton.

SteWART, A., and Weber, F. P. (1938): Myelomatosis, Quart. F. Med., N.S. 7, 21 I.

UEHLINGER, E. (1949): UUber eine Blutgerinnungsstörung bei Dysproteinämie (Beitrag zur Kenntniss der Korpereigenen Antikoagulantia), Helv. med. acta., 16, 508.

Verstraete, M., and Vermylen, C. (1959): Rechercher l'antithrombine, 5. Dans la Maladie de Kahler, Acta hoemat., 22, 240.

Wintrobe, M. M., and Buell, M. V. (I933): Hyperproteinemia Associated with Multiple Myeloma, with Report of a Case in which Extraordinary Hyperproteinemia was Associated with Thrombosis of Retinal Veins and Symptoms suggesting Raynaud's Disease, Bull. Fohns Hopk. Hosp., 52, 156.

(1961): 'Clinical Hæmatology', 5th Edition, pp. 1068, 1069. London: Kimpton. 